\title{
Upaya Guru BK/Konselor untuk Menurunkan Perilaku Agresif Siswa dengan Menggunakan Konseling Kreatif dalam Bingkai Modifikasi Kognitif Perilaku
}

\author{
Yeni Karneli, Firman, Netrawati \\ Universitas Negeri Padang, Padang \\ Email: yenikarneli.unp@gmail.com
}

\begin{abstract}
Abstrak
Masa remaja merupakan masa yang rentan dengan perubahan berupa perubahan biologis, kognitif dan sosio-emosional. Perilaku remaja sebagai luapan emosi negatif dan suasana hati yang tidak menentu akan ditampilkan dalam bentuk perilaku agresif, seperti: memukul, menyerang, memaki, mengeluarkan kata-kata kasar, mengancam, memalak dan lain sebagainya. Perilaku agresif adalah perilaku fisik atau verbal yang dimaksudkan untuk merusak atau melukai orang lain, yang mengakibatkan orang lain mengalami penderitaan, sehingga mendatangkan kesusahan baik fisik maupun psikologis. Penelitian ini bertujuan untuk: 1) membantu siswa menurunkan perilaku agresif dengan menggunakan konseling pendekatan kognitif perilaku, 2) memberikan keterampilan pada guru $\mathrm{BK} /$ konselor untuk terampil menggunakan konseling kreatif dalam bingkai kognitif perilaku. Penelitian ini menggunakan metode deskriptif melalui penelitian action reseach yang terdiri dari dua siklus dengan memberikan apersepsi dan tindakan dengan pendekatan konseling kreatif dalam bingkai kognitif perilaku. Subjek penelitian adalah siswa SMP dan guru BK/konselor di SMP. Instrumen dan teknik pengumpulan data adalah interview dan observasi. Hasil yang diperoleh berupa dampak bertambahnya keterampilan guru BK dalam melaksanakan intervensi konseling kreatif dalam bingkai kognitif perilaku yang berfokus pada pembahasan penurunan perilaku agresif siswa. Secara keseluruhan dari kedua siklus tersebut terdapat perubahan keterampilan yang dimiliki gurur $\mathrm{BK} /$ konselor dalam menangani perilaku agresif siswa.
\end{abstract}

Kata Kunci: Perilaku Agresif, Konseling Kreatif, Kognitif Perilaku

\section{PENDAHULUAN}

Permendikbud No. 111 Tahun 2014 Pasal 3, menyatakan bahwa layanan bimbingan dan konseling memiliki tujuan membantu peserta didik/klien mencapai perkembangan optimal dan kemandirian secara utuh dalam aspek pribadi, belajar, sosial, dan karir. Guru BK/konselor yang kreatif diharapkan mampu memberikan layanan dalam rangka mencapai perkembangan optimal dan kemandirian yang utuh. Guru BK/konselor yang kreatif mampu mengentaskan berbagai macam masalah siswa yang berkembang di sekolah antara lain mampu mencegah tindakan kekerasan dan menurunkan tingkah laku agresif siswa yang terjadi di sekolah (Netrawati, Khairani, \& 
Karneli, 2018).

Perilaku agresif yang dilakukan siswa di SMP, dari tahun ke tahun terjadi peningkatan. Hal ini bisa dipahami karena siswa SMP berada pada rentangan usia remaja. Masa remaja merupakan masa yang rentan dengan berbagai perubahan karena dalam diri individu remaja terjadi ketidakseimbangan dan ketidakstabilan pada aspek emosional, hubungan sosial serta mulai mencari identitas dirinya dengan pola hubungan sosial yang mulai berubah. Perubahan yang terjadi dalam diri remaja yaitu berupa perubahan biologis, kognitif dan sosio-emosional (Santrock 2005), seperti ingin menyendiri, bosan, hilangnya kepercayaan diri, karena adanya perubahan hormonal. Faktor-faktor yang memengaruhi gejolak emosi remaja, yaitu gender, usia, temperamen, stress, pola makan, relasi sosial, faktor sosial penyebab depresi, dan kemarahan.

Perilaku remaja sebagai luapan emosi negatif dan suasana hati yang tidak menentu akan ditampilkan dalam bentuk perilaku agresif, seperti memukul, menyerang, memaki, mengeluarkan kata-kata kasar, mengancam, memalak dan lain sebagainya. Hal ini sesuai dengan studi yang dilakukan Warburton (2015) terhadap siswa sekolah menengah dari 25 sekolah menengah di Kanada terdapat beberapa masalah perilaku remaja yang tergolong perilaku agresif seperti merokok, aktivitas seksual, mencuri, kenakalan besar antara lain membawa senjata, bergabung dengan geng, mendorong, menendang dan memukul seseorang.

Perilaku agresif adalah perilaku fisik atau verbal yang dimaksudkan untuk merusak atau melukai orang lain. Perilaku agresif merupakan perbuatan yang mengakibatkan orang lain mengalami penderitaan, sehingga mendatangkan kesusahan baik fisik maupun psikologis. Firman (2016) perilaku agresif disebabkan oleh persoalan kecil, seperti kesalahpahaman, ketidakpuasan, dan pertengkaran yang berakhir dengan pembunuhan, pembakaran, serta merusak fasilitas milik pribadi maupun umum. Berbagai peristiwa tindakan kekerasan dan agresivitas yang menggemparkan dilakukan oleh siswa sekolah menengah. Komisi Perlindungan Anak Indonesia (KPAI) saat ini mencatat ada 1000 kasus kekerasan dalam kurun waktu selama tahun 2016. Selanjutnya perilaku agresif tidak hanya dilakukan di Indonesia, tetapi juga dibanyak negara seperti Amerika Serikat. Menurut Puzzanchera, Stahl, Finnegan, Tierney, dan Snyder dalam Saputra, Hanifah, \& Widagdo (2017) perilaku agresif berdasarkan gender antara tahun 1985 sampai 2000 terjadi pada anak laki- laki sebesar 34\%, sedangkan pada anak perempuan yang terlibat sebesar $83 \%$.

Berdasarkan data Pusat Pengendalian Gangguan Sosial DKI Jakarta antara tahun 2009 sampai 2016 terdapat $0,08 \%$ atau 1.318 dari 1.647.835 siswa SD, SMP dan SMA di DKI Jakarta terlibat tawuran. Tawuran dan kekerasan terjadi pada siswa merupakan bentuk dari luapan emosi negatif remaja yang tidak terkendali yang disebut dengan agresivitas, sehingga dapat menyakiti dan merugikan orang lain. Berkowitz dalam Zahri \& Savira (2017) menjelaskan agresif merupakan segala bentuk perilaku untuk menyakiti seseorang baik secara fisik maupun mental. Agresif dianggap sebagai pengiriman stimulus berbahaya kepada orang lain, tanpa dihubungkan dengan niat dan mengganggap perilaku ini sebagai pelanggaran norma sosial, yang dilakukan dalam bentuk fisik maupun verbal secara langsung dan tidak langsung.

Untuk daerah Sumatera Barat memasuki tahun 2016, Nurani Perempuan Women's Crisis Center (NPWCC) melakukan pendampingan terhadap 103 kasus kekerasan sebagai akibat dari perilaku agresif. Kasuskasus tersebut adalah kasus yang terjadi dalam rentang 2013-2015 yang belum terselesaikan (Harian Haluan, 2016). Selanjutnya sejak awal 2016 sampai akhir 2017 terdapat 143 kasus kekerasan berasal dari 19 kabupaten/kota di Sumatra Barat. Kasus terbanyak berasal dari Kabupaten Pasaman Barat. Polres Pasaman Barat mencatat selama tahun 2016 kasus kekerasan mencapai 95 kasus dan ini tertinggi jika dibandingkan dengan kabupaten kota lainnya di Sumatera Barat. Di tahun 2017 pada triwulan pertama kasus kekerasan sudah terjadi sebanyak 27 kasus (Andries, 2017).

Perilaku agresif disebabkan oleh beberapa faktor, seperti konsep diri yang tidak baik. Netrawati et al (2018) peningkatan perilaku agresif pada pasangan selama 
pacaran dibuktikan dengan adanya kekerasan dalam pacaran seperti fisik, ekonomi, seksual dan verbal. Hasil analisis data diperoleh $52.27 \%$ memiliki konsep diri positif dan $47.73 \%$ memiliki konsep diri negatif yang diiringi dengan perilaku agresif. Perilaku agresif merupakan perilaku yang merugikan dan merusak, baik sengaja atau tidak sengaja. Sarwono (1997) menjelaskan agresif merupakan ungkapan perasaan dengan kemarahan yang disertai emosi tinggi sebagai sarana untuk mencapai tujuan tertentu. Kekerasan yang berdampak terhadap perilaku agresif terjadi ketika anak minta perlindungan dan perhatian lalu orang tua mengabaikannya. Hasil penelitian Netrawati, Furqon, Yusuf, \& Rusmana (2016) pendekatan konseling transaksional analisis sangat efektif untuk membantu menurunkan perilaku agresif siswa di sekolah.

Pelaksanaan layanan bimbingan di sekolah merupakan salah satu upaya pecegahan perilaku agresif. Dalam proses konseling pencegahan perilaku agresif diusahakan melalui suatu proses belajar (learning) atau belajar kembali (relearning). Oleh karena itu proses konseling dipandang sebagai suatu proses pendidikan (an educational process) yang berpusat pada usaha membantu dan kesediaan dibantu untuk belajar perilaku baru dan dapat mengatasi permasalahan yang ada. Pengembangan potensi siswa akan lebih baik difokuskan pada aspek-aspek kognitif positif daripada menyoroti sisi kognitif negatifnya. Menurut Beck (1976) perubahan perilaku dan afeksi terjadi melalui perubahan kognisi. Untuk itu intervensi yang digunakan harus melibatkan proses kognitif dalam rangka mengubah perilaku klien.

Konseling kreatif dalam bingkai modifikasi kognitif perilaku bertujuan membantu klien mengubah perilaku dengan memfokuskan pada kemampuan kognitif dan perilaku klien, menekankan pada konseling membelajarkan diri sendiri dan menolong klien menjadi lebih sadar akan kata-kata yang diarahkan pada dirinya sendiri, sehingga mereka bisa menangani secara lebih efektif masalah mereka. Selain itu, pendekatan konseling modifikasi kognitif perilaku lebih menekankan pada keaktifan klien, waktunya singkat dan disusun secara terbuka, sehingga sangat sesuai untuk diterapkan pada remaja di sekolah.

Penelitian yang dilakukan oleh Meichenbaum dalam Corey (2007) menunjukkan kesuksesan konseling dengan pendekatan konseling modifikasi kognitif perilaku dalam merestrukturisasi kognitif manakala diaplikasikan pada problema akademik, termasuk perilaku agresif dalam belajar. Kesuksesan pengaplikasian pendekatan konseling modifikasi kognitif perilaku dalam merestrukturisasi kognitif yang mal-adaptif, membuktikan pendekatan konseling modifikasi kognitif perilaku efektif untuk menurunkan perilaku agresif.

Kemudahan dalam prosedur yang digunakan serta tidak banyak menyita waktu berinteraksi antara konselor dengan klien, menjadi alasan lain peneliti untuk melaksanakan konseling kreatif dalam bingkai modifikasi kognitif perilaku. Adapun tahapan pelaksanaan konseling:

\section{Observasi diri}

Di awal konseling klien diminta untuk mendengarkan dialog internal dalam diri mereka dan mengenali karakteristik pernyataan negatif yang ada. Proses ini melibatkan kegiatan meningkatkan sensitivitas terhadap pikiran, perasaan, perbuatan, reaksi fisiologis dan pola reaksi terhadap orang lain.

\section{Membuat dialog internal baru}

Setelah klien belajar mengenali tingkah laku maladaptifnya, mereka mulai mencari kesempatan untuk mengembangkan alternatif tingkah laku adaptif, dengan cara mengubah dialog internal dalam diri mereka. Dialog internal yang baru diharapkan dapat menghasilkan tingkah laku baru, yang sebaliknya akan memberikan dampak terhadap struktur kognisi klien.

3. Belajar keterampilan baru

Klien kemudian belajar teknik mengatasi masalah yang secara praktis dapat diterapkan dalam kehidupan seharihari. Pada saat yang sama, klien diharapkan untuk tetap memusatkan perhatiannya kepada tugas membuat pernyataan baru dan mengamati perbedaan hasilnya 


\section{METODE}

Metode yang digunakan dalam penelitian ini adalah penelitian action research dalam setting pelayanan bimbingan dan konseling dengan menggunakan konseling kreatif dalam bingkai kognitif perilaku. Penelitian ini dilakukan dengan tujuan untuk membantu guru BK SMP. Dengan metode penelitian action research dapat menguji ketepatan guru $\mathrm{BK} /$ konselor dalam memberikan treatment kepada siswa SMP yang mengalami perilaku agresif. Model yang digunakan dalam penelitian ini dibagi empat komponen 1) planning 2) acting 3) observing 4) reflecting. Subjek penelitian adalah 150 orang siswa SMP dan 30 orang guru $\mathrm{BK} /$ konselor. Penelitian ini dilakukan di Pasaman Barat.

\section{HASIL PENELITIAN DAN PEMBAHASAN}

Penelitian ini menggunakan pendekatan konseling kreatif dalam bingkai kognitif perilaku untuk menurunkan perilaku agresif siswa. Proses penelitian ini kolaborasi peneliti dengan konselor SMP Pasaman Barat. Penelitian ini dilakukan pada 150 orang siswa dan 30 orang guru BK/konselor. Berdasarkan hasil observasi.

Kajian tentang perilaku agresif menarik dilakukan di SMP karena siswa berada pada rentangan usia remaja. Masa remaja merupakan masa yang rentan dengan perubahan karena terjadi ketidakseimbangan dan ketidakstabilan pada aspek emosional, hubungan sosial serta mulai mencari identitas dirinya dengan pola hubungan sosial yang mulai berubah. Perubahan yang terjadi dalam diri remaja yaitu berupa perubahan biologis, kognitif dan sosio-emosional (Azmi, 2015), seperti ingin menyendiri, bosan, hilangnya kepercayaan diri, karena adanya perubahan hormonal. Faktor-faktor yang mempengaruhi gejolak emosi remaja, yaitu gender, usia, temperamen, stress, pola makan, relasi sosial, faktor sosial penyebab depresi, dan kemarahan. Perilaku remaja sebagai luapan emosi negatif dan suasana hati yang tidak menentu akan ditampilkan dalam bentuk perilaku agresif, seperti memukul, menyerang, memaki, mengeluarkan kata-kata kasar, mengancam, memalak dan lain sebagainya. Hal ini sesuai dengan studi yang dilakukan Warburton \& Anderson (2015) terhadap siswa sekolah menengah dari 25 sekolah menengah di Kanada terdapat beberapa masalah perilaku remaja yang tergolong perilaku agresif seperti merokok, aktivitas seksual, mencuri, kenakalan besar antara lain membawa senjata, bergabung dengan geng, mendorong, menendang dan memukul seseorang. Perilaku agresif lainnya seperti menyebar rumor dengan berani kepada siswa lain untuk menyakitinya.

Perilaku agresif adalah perilaku fisik atau verbal yang dimaksudkan untuk merusak atau melukai orang lain. Perilaku agresif merupakan perbuatan yang mengakibatkan orang lain mengalami penderitaan, sehingga mendatangkan kesusahan baik fisik maupun psikologis. Firman (2016) perilaku agresif disebabkan oleh persoalan kecil, seperti kesalahpahaman, ketidakpuasan, dan pertengkaran yang berakhir dengan pembunuhan, pembakaran, serta merusak fasilitas milik pribadi maupun umum. Berbagai peristiwa tindakan kekerasan dan agresivitas yang menggemparkan dilakukan oleh siswa sekolah menengah. Komisi Perlindungan Anak Indonesia (KPAI) saat ini mencatat ada 1000 kasus kekerasan dalam kurun waktu selama tahun 2016. Selanjutnya perilaku agresif tidak hanya dilakukan di Indonesia, tetapi juga dibanyak negara seperti Amerika Serikat. Menurut Puzzanchera, Stahl, Finnegan, Tierney, dan Snyder dalam Kostelecky \& Lempers (2014) perilaku agresif berdasarkan gender antara tahun 1985 sampai 2000 terjadi pada anak laki-laki sebesar 34\%, sedangkan pada anak perempuan yang terlibat sebesar $83 \%$.

Berdasarkan data Pusat Pengendalian Gangguan Sosial DKI Jakarta antara tahun 2009 sampai 2016 terdapat $0,08 \%$ atau 1.318 dari 1.647.835 siswa SD, SMP dan SMA di DKI Jakarta terlibat tawuran. Tawuran dan kekerasan terjadi pada siswa merupakan bentuk dari luapan emosi negatif remaja yang tidak terkendali yang disebut dengan agresivitas, sehingga dapat menyakiti dan merugikan orang lain. Berkowitz dalam Zahri \& Savira (2017) menjelaskan agresif merupakan segala bentuk perilaku untuk 
menyakiti seseorang baik secara fisik maupun mental. Agresif dianggap sebagai pengiriman stimulus berbahaya kepada orang lain, tanpa dihubungkan dengan niat dan mengganggap perilaku ini sebagai pelanggaran norma sosial, yang dilakukan dalam bentuk fisik maupun verbal secara langsung dan tidak langsung.

Untuk daerah Sumatera Barat memasuki tahun 2016, Nurani Perempuan Women's Crisis Center (NPWCC) melakukan pendampingan terhadap 103 kasus kekerasan sebagai akibat dari perilaku agresif. Kasuskasus tersebut adalah kasus yang terjadi dalam rentang 2013-2015 yang belum terselesaikan (Harian Haluan, 2016). Selanjutnya sejak awal 2016 sampai akhir 2017 terdapat 143 kasus kekerasan berasal dari 19 kabupaten/kota di Sumatra Barat. Kasus terbanyak berasal dari kabupaten Pasaman Barat. Polres Pasaman Barat mencatat selama tahun 2016 kasus kekerasan mencapai 95 kasus dan ini tertinggi jika dibandingkan dengan kabupaten kota lainnya di Sumatera Barat. Di tahun 2017 pada triwulan pertama kasus kekerasan sudah terjadi sebanyak 27 kasus (Andries, 2017).

Perilaku agresif disebabkan oleh beberapa faktor, seperti konsep diri yang tidak baik. Netrawati et al (2018) peningkatan perilaku agresif pada pasangan selama pacaran dibuktikan dengan adanya kekerasan dalam pacaran seperti fisik, ekonomi, seksual dan verbal. Hasil analisis data diperoleh 52.27\%) memiliki konsep diri positif dan $47.73 \%$ memiliki konsep diri negatif yang diiringi dengan perilaku agresif. Perilaku agresif merupakan perilaku yang merugikan dan merusak, baik sengaja atau tidak sengaja. Sarwono (1997) menjelaskan agresif merupakan ungkapan perasaan dengan kemarahan yang disertai emosi tinggi sebagai sarana untuk mencapai tujuan tertentu. Kekerasan yang berdampak terhadap perilaku agresif terjadi ketika anak minta perlindungan dan perhatian lalu orang tua mengabaikannya. Hasil penelitian Netrawati et al (2016) pendekatan konseling transaksional analisis sangat efektif untuk membantu menurunkan perilaku agresif siswa di sekolah.

Bandura dalam Huesmann (1994) menjelaskan perilaku agresif diperoleh melalui belajar, dan dipelihara dengan pengalaman dari lingkungan baik secara langsung atau dialami sendiri. Pembelajaran agresi dikendalikan oleh penguatan dan hukuman dengan cara yang mirip dengan pembelajaran setiap perilaku baru. Perilaku baru akan dihindari pada masa depan jika perilaku tersebut dihukum. Peningkatan perilaku agresif yang terjadi pada siswa didorong oleh proses meniru perbuatan orang lain, di mana proses peniruan ini sangat dipengaruhi oleh faktor kognitif. Untuk itu proses konselingnya akan lebih baik difokuskan pada aspek-aspek kognitif positif dari pada menyoroti sisi kognitif negatifnya. Menurut Beck (1976) perubahan perilaku dan afeksi terjadi melalui perubahan kognisi. Untuk itu intervensi yang digunakan harus melibatkan proses kognitif dalam rangka mengubah perilaku klien.

Berdasarkan hasil tersebut, menunjukkan bahwa ada perbedaan yang signifikan antara konseli yang mendapat intervensi pendekatan konseling modifikasi kognitif perilaku (KMKP) dan konseli yang mendapat usually counseling. Selain itu perbedaan juga ditunjukkan melalui perolehan skor skala stres akademik konseli yang diberi intervensi pendekatan konseling modifikasi kognitif perilaku (KMKP) lebih rendah pada saat pemberian post-test. Dengan demikian, hasil penelitian ini menunjukkan bahwa pendekatan konseling modifikasi kognitif perilaku (KMKP) efektif untuk menurunkan stres akademik siswa SMK.

Hasil penelitian ini mendukung hasil penelitian sebelumnya yang dilakukan Wahyuni (2017) tentang keefektifan pendekatan Cognitive Behavior Modivication untuk mengelola stres belajar siswa di SMPI Sabilillah Kota Malang. Mencermati beberapa hasil penelitian di atas, maka dalam penelitian ini dapat ditegaskan kembali bahwa pendekatan konseling modifikasi kognitif perilaku (KMKP) efektif untuk menurunkan stres akademik siswa.

Berdasarkan berbagai hasil penelitian yang dikemukakan di atas, dapat dijadikan bukti (evidence) yang kuat untuk dilakukan penelitian ini sebagai upaya untuk menurunkan stres akademik siswa melalui intervensi konseling kognitif perilaku (KMKP). Dalam penelitian ini, yang menjadi salah satu faktor keberhasilan pendekatan konseling modifikasi kognitif perilaku (KMKP) untuk menurunkan 
stres akademik adalah karena lebih menekankan pada konseling membelajarkan diri sendiri. Proses konselingnya terdiri atas melatih konseli memodifikasi pembelajaran yang diberikan kepada dirinya sendiri sehingga mereka bisa menangani masalah yang mereka hadapi lebih efektif. Selain itu pendekatan konseling modifikasi kognitif perilaku (KMKP) menekankan pada keaktifan klien, waktunya singkat, dan disusun secara terbuka, sehingga sesuai untuk diterapkan pada siswa di sekolah.

$\begin{array}{ccc}\text { Pendekatan } & \text { konseling modifikasi } \\ \text { kognitif perilaku } & \text { (KMKP) } & \text { merupakan }\end{array}$ konseling yang menggabungkan terapi kognitif dan bentuk modifikasi perilaku (Sa'adah \& Rahman, 2015). Individu yang akan bertindak, didahului adanya proses berpikir, sehingga untuk mengubah suatu perilaku yang tidak adaptif akibat stres akademik yang dialaminya, harus terlebih dahulu memahami aspek-aspek yang berada dalam pengalaman kognitif dan usaha untuk membangun perilaku adaptif melalui mempelajari keterampilanketerampilan yang terdapat pada terapi kognitif behavior dan mengaplikasikannya pada kehidupan sehari-hari (Sa'adah \& Rahman, 2015). Jadi pendekatan pendekatan konseling modifikasi kognitif perilaku (KMKP) memandang stres akademik sebagai suatu yang alami yang terjadi pada siswa, sehingga dengan mengajarkan sejumlah keterampilan dalam menurunkan stres akademik akan membantu siswa dalam mengembangkan kognisi, emosi dan perilakunya ke arah yang positif.

Stres akademik timbul dari penilaian kognitif mengenai kemampuan yang dimilikinya, yang terdiri komponen-komponen seperti kognitif, emosi dan perilaku yang terbentuk dari stimulus-kognisi-respon (SKR) yang saling berkait dalam otak manusia. Proses kognitif akan menjadi faktor penentu dalam menjelaskan bagaimana manusia berpikir, merasa dan bertindak (Kurniawan \& Sulistyarini, 2017). Hal ini memiliki makna bahwa stres akademik muncul dari penilaian kognitif yang disebabkan oleh cara berpikir siswa yang mengalami penyimpangan (maladaptif). Stres akademik muncul ketika harapan untuk pencapaian prestasi belajar meningkat, baik dari orang tua, guru, ataupun teman sebaya dan harapan tersebut tidak sesuai dengan kemampuan siswa (Barseli \& Ifdil, 2017). Persepsi siswa yang mengganggap tuntutan belajar sebagai beban berakibat pada perasaan negatif berupa tidak siap dan terancam kenyamanan dalam menjalani kegiatan belajar baik di sekolah maupun di rumah.

Pendekatan konseling modifikasi kognitif perilaku (KMKP) berupaya untuk memodifikasi pikiran, emosi dan perilaku siswa secara mandiri untuk mengubah pemikiran yang mal-adaptif dengan mengaplikasikan teknik time management yang telah diajarkan konselor di sekolah dalam kehidupan sehari-hari. Keterampilan baru yang diberikan konselor dalam pendekatan konseling modifikasi kognitif perilaku (KMKP) akan menjadi sumber kekuatan bagi siswa dalam menurunkan stres akademiknya. (Meichenbaum, 2004).

\section{SIMPULAN DAN SARAN}

Dari hasil penelitian dapat disimpulkan bahwa setelah dilakukan workshop dan pelatihan konseling kreatif dalam bingkai kognitif perilaku untuk membantu menurunkan perilaku agresif siswa berdampak positif terhadap keterampilan guru BK/konselor. Dampak yang terlihat antara lain sebelumnya guru $\mathrm{BK} /$ konselor belum menggunakan konseling kreatif dalam bingkai kognitif perilaku untuk membantu menurunkan perilaku agresif siswa, hal tersebut dapat dilihat dari perbandingan antara hasil siklus ke satu dengan siklus ke dua, yaitu adanya peningkatan pengetahuan dan keterampilan gurur BK/konselor dalam melaksanakan konseling kreatif dalam bingkai modifikasi kognitif perilaku.

\section{DAFTAR PUSTAKA}

Andries, R. S. (2017, April 5). Pelecehan Seksual pada Anak di Pasbar Tertinggi di Sumbar. Harian Haluan. Retrieved from https://www.harianhaluan.com/news/detai 1/64445/pelecehan-seksual-pada-anak-dipasbar-tertinggi-di-sumbar

Azmi, N. (2015). Potensi Emosi Remaja dan Pengembangannya. Jurnal Pendidikan 
Sosial, 2(1), 36-46.

Barseli, M., \& Ifdil, I. (2017). Konsep Stres Akademik Siswa. Jurnal Konseling Dan Pendidikan, 5(3), 143-148.

Beck, A. . (1976). Cognitive Therapy of Personality Disorder. London: The Guilford Press.

Corey, G. (2007). Theory and Practice of Counseling and Psychotherapy (6th ed.). California: Books Cole Publishing.

Firman, F. (2016). Penanggulangan Tindakan Kekerasan dan Agresivitas Remaja Remaja Kota Padang. Padang: FIP UNP.

Harian Haluan. (2016, January 13). NPWCC Dampingi 103 Kasus Kekerasan di Sumbar. Harian Haluan. Retrieved from https://www.harianhaluan.com/news/detai 1/47095/npwcc-dampingi-103-kasuskekerasan-di-sumbar

Huesmann, L. R. (1994). Aggresive Behavior Current Perspectives. New York: Plenum Press.

Kurniawan, Y., \& Sulistyarini, I. (2017). Terapi Kognitif Perilaku untuk Mengurangi Episode Depresi Berat dengan Gejala Psikotik. Philantrophy Journal of Psychology, 1(1), 65-75.

Netrawati, Furqon, Yusuf, S., \& Rusmana, N. (2016). Solving Adolescent Verbal Aggressions through Transactional Analysis Counseling Approach. Journal of Education and Practice, 7(18), 169177.

Netrawati, N., Khairani, K., \& Karneli, Y. (2018). Upaya Guru BK untuk Mengentaskan Masalah-masalah Perkembangan Remaja dengan Pendekatan Konseling Analisis Transaksional. Islamic Counseling:
Jurnal Bimbingan Konseling Islam, 2(1), 79-90.

https://doi.org/10.29240/jbk.v2i1.463

Sa'adah, F. M., \& Rahman, I. K. (2015). Konsep Bimbingan dan Konseling Cognitive Behavior Therapy (CBT) dengan Pendekatan Islam untuk Meningkatkan Sikap Altruisme Siswa. Jurnal Hisbah, 12(2), 49-59.

Santrock, J. W. (2005). Adolescence, Perkembangan Remaja. Jakarta: Erlangga.

Saputra, W. N. E., Hanifah, N., \& Widagdo, D. N. (2017). Perbedaan Tingkat Perilaku Agresi Berdasarkan Jenis Kelamin pada Siswa Sekolah Menengah Kejuruan Kota Yogyakarta. Jurnal Kajian Bimbingan Dan Kon, 2, 142-147.

Sarwono. (1997). Psikologi Sosial. Jakarta: Balai Pustaka.

Wahyuni, E. N. (2017). Mengelola Stres dengan Pendekatan Cognitive Behavior Modification (Studi Eksperimen Pada Mahasiswa Baru Pendidikan Agama Islam (PAI) Fakultas Ilmu Tarbiyah \& Keguruan UIN Maliki). Jurnal Tadrib, III(1). https://doi.org/10.19109/Tadrib.v3i1.1385

Warburton, W. A., \& Anderson, C. A. (2015). Aggression, Social Psychology of. International Encyclopedia of Social \& Behavioral Sciences, 1, 295-299. https://doi.org/10.1016/B978-0-08097086-8.24002-6

Zahri, H., \& Savira, I. (2017). Pengaruh SelfControl terhadap Agresivitas Remaja pada Pelajar SMP dan SMU di Sekolah Perguruan Nasional. Jurnal JP3SDm, 110. 